\title{
R22 ve Alternatifleri R438A ile R417A Soğutucu Akışkanları için Kızılötesi Görüntü İşleme Teknikleri Kullanarak, Soğutma Sistem Performansının İncelenmesi
}

\author{
${ }^{1}$ Ferzan Katırcıoğlu, *2Zafer Cingiz, ${ }^{3}$ Yusuf Çay, ${ }^{4}$ A. Etem Gürel, ${ }^{5}$ Suat Sarıdemir, ${ }^{6}$ Ahmet Kolip \\ ${ }^{1}$ D.Ü. Düzce MYO Elekt. ve Otomasyon Böl. Düzce, ferzankatircioglu@duzce.edu.tr (D) \\ ${ }^{2}$ D.Ü. Düzce MYO Elektrik ve Enerji Böl. Düzce, zafercingiz@duzce.edu.tr (D) \\ ${ }^{3}$ SUBÜ Teknoloji Fak. Makine Müh. Böl. Sakarya, ycay@subu.edu.tr \\ ${ }^{4}$ D.Ü. Teknoloji Fak. Makine ve İmalat Müh. Böl. Düzce, alietemgurel@duzce.edu.tr (iD \\ ${ }^{5}$ D.Ü. Tekn. Fak. Makine ve İmalat Müh. Böl. Düzce, suatsaridemir@duzce.edu.tr (D) \\ ${ }^{6}$ SUBÜ Teknoloji Fak. Makine Müh. Böl. Sakarya, akolip@subu.edu.tr iD
}

Günümüzde çeşitli protokoller ile halojenik kloroflorokarbon (CFC) ve hidrokloroflorokarbon (HCFC) soğutucu akışkanlarının ilerleyen zamanlarda kullanılmayacağı ve bu akışkanlara çeşitli alternatiflerin oluşturulması gerektiği gözlemlenmiştir. Geleneksel soğutma etkinlik katsayısı (COP) hesaplama yönteminde, termodinamik özellik tabloları ve basınç-entalpi diyagramları kullanılmaktadır. Önerilen yöntem sayesinde, COP hesaplanırken, bu tablo ve diyagramların kullanılmasına gerek duyulmayacaktır. Kızılötesi görüntüleme sistemi ile belirtilen bölgelerden görüntü alınması yeterli olacaktır. Bu çalışmada, R22 akışkanına alternatif olan, ozon tabakasına dost R417A ve R438A akışkanlarının ticari soğutma sistemlerine yönelik performans analizi yapılmıştır. CFC gazların tüketiminin yasaklanması ile birlikte gelinen süreçte ozon tabakasına zarar veren diğer bir gaz grubu olan HCFC gazların da kullanımı önce sınırlandırılmış ardından tamamen yasaklanmıştır. Bu gazlardan en çok kullanılanı R22 gazıdır. Referans R22 gazı ile R438A ve R417A gazlarının performansları kızı̈ötesi görüntü analizi ile gerçekleştirmek için bölgesel öz nitelik veri elde edinimi ile COP olmak üzere iki yöntem önerilmiştir. Ayrıca gerçekleştirilen iki ara yüz üzerinde, kızılötesi görüntülerden elde edilen büyüklükler, grafiksel ve sayısal olarak karşılaştırılmaktadır. Elde edilen sayısal ve görsel uygulama sonuçlarına göre, R22 gazına en yakın performansı R438A göstermiştir. Geleneksel hesaplamalı performans testlerine göre, uygulanan sistemin kullanım kolaylığı, uzaktan ölçüm ve eş zamanlı kayıt alma noktasında daha avantajlı olduğunu göstermiştir.

Anahtar Kelimeler: Kızılötesi görüntü işleme, COP, soğutucu akışkan

\section{Investigation of refrigeration system performance using infrared image processing techniques for $R 22$ and its alternatives, $R 438 A$ and $R 417 A$ refrigerants.}

\author{
${ }^{1}$ Ferzan Katırcıoğlu, *2Z Zafer Cingiz, ${ }^{3}$ Yusuf Çay, ${ }^{4}$ A. Etem Gürel, ${ }^{5}$ Suat Sarıdemir, ${ }^{6}$ Ahmet Kolip \\ ${ }^{1}$ D.Ü. Düzce MYO Elekt. ve Otomasyon Böl. Düzce, ferzankatircioglu@duzce.edu.tr, iD \\ ${ }^{2}$ D.Ü. Düzce MYO Elektrik ve Enerji Böl. Düzce, zafercingiz@ duzce.edu.tr, \\ ${ }^{3}$ SUBÜ Teknoloji Fak. Makine Müh. Böl. Sakarya, ycay@subu.edu.tr, \\ ${ }^{4}$ D.Ü. Teknoloji Fak. Makine ve İmalat Müh. Böl. Düzce, alietemgurel@duzce.edu.tr, \\ ${ }^{5}$ D.Ü. Tekn. Fak. Makine ve İmalat Müh. Böl. Düzce, suatsaridemir@duzce.edu.tr, (D) \\ ${ }^{6}$ SUBÜ Teknoloji Fak. Makine Müh. Böl. Sakarya, akolip@subu.edu.tr,
}

\begin{abstract}
Today, it has been observed that with various protocols, halogenic chlorofluorocarbon (CFC) and hydrochlorofluorocarbon (HCFC) refrigerants will not be used in the future and various alternatives must be created. In the conventional cooling efficiency coefficient (COP) calculation method, thermodynamic property tables and pressure-enthalpy diagrams are used. Thanks to the

\footnotetext{
*Sorumlu yazar: Elektrik ve Enerji Bölümü, Düzce Meslek Yüksek Okulu, Düzce Üniversitesi, 81010 Düzce, Turkey. zafercingiz@duzce.edu.tr, +90380 5240098.
} 
proposed method, it will not be necessary to use these tables and diagrams when calculating the COP. It will be sufficient to take images from the regions indicated by the infrared imaging system. In this study, performance analysis of commercial refrigeration systems of R417A and R438A fluids that are alternative to R22 fluid, which are friendly to the ozone layer, has been performed. With the prohibition of the consumption of CFC gases, the use of HCFC gases, another gas group that damages the ozone layer, has been restricted and then banned. The most used of these gases is R22 gas. In order to perform the performances of reference R22 gas and R438A and R417A gases with infrared image analysis, two methods are proposed: COP with regional feature data acquisition and COP. In addition, on the two interfaces realized, the sizes obtained from infrared images are compared graphically and numerically. According to the obtained numerical and visual application results, R438A showed the closest performance to R22 gas. Compared to traditional computational performance tests, the ease of use of the system has shown that it is more advantageous in terms of remote measurement and simultaneous recording.

Keywords: Infrared image processing, COP, refrigerant

\section{GİRIŞ}

Mevcut çalışmalar soğutucu akışkanların performanslarını termodinamiğin birinci ve ikinci yasası çerçevesinde incelemekte ve buna göre performans değerlendirmesi sunmaktadır. Soğutma insanoğlu için vazgeçilmez ihtiyaçtır. Çünkü soğutma gıdaların korunmasında, her türlü konfor sistemlerinde (konutlar, taşıtlar, iş yerleri vb.), sanayide, sağlık sektöründe kısacası birçok alanda yaygın olarak kullanılmaktadır. Soğutma sistemleri, özellikle endüstride kullanılanları gittikçe önem kazanmaktadır. Refah seviyesinin yükselmesiyle birlikte tüketim maddelerinde aranan kaliteyi de, beraberinde getirmektedir. Özellikle gıda maddelerinin ilk üretildiğindeki tazeliğini ve özelliklerini koruyabilmesi ancak uygun sicaklık ve nem ortamı oluşturularak saklanabilmesiyle sağlanabilir. Literatür incelendiğinde, R22 ve alternatifleri olan R417A ve R438A soğutucu akışkanları için deneysel ve teorik çalışmaların olduğu, genelde performans ile verimlilik üzerine yoğunlaşılmış olduğu görülmektedir. Allgood ve diğ.., yaptıkları çalışmada, mevcut soğutma ve iklimlendirme sistemlerinde R438A'yı denemiş ve R22'ye kıyasla benzer soğutma performansı ve enerji verimliliğinin elde edildiğini bildirmiştir. Yenileme sırasında yağ değişiminde herhangi bir değişiklik olmadan düşük deşarj sıcaklığı, benzeri evaporatör ve kondenser basıncı gözlenmiştir [1]. Baraz, yaptığ1 çalışmasında doğrudan genleşmeli sistemlerde alternatif soğutucu akışkanlar kullanmıştır. R22 alternatiflerinden R422D ve R417A soğutucu akışkanları teorik ve deneysel kullanılmış ve sonuçlar karşılaştırılmıştır [2]. BOCK Kompresörleri, kompresörlerinde R422D (MO29), R417A (MO59) ve R438A (MO99) değerlerini test etmişler ve üç alternatif soğutucu arasında sıkıştırma sıcaklığının R417A için en düşük olduğunu bulmuşlardır; R438A en yüksek soğutma kapasitesine sahipken R417A, R22'ye kıyasla en yüksek enerji verimliliğine sahip olduğu görülmüştür [3]. Ergün ve diğ., yaptıkları çalışmada, özellikle soğuk depoculukta ve iklimlendirme sistemlerinde oldukça yaygın olarak kullanılan R-22 soğutucu akışkanına alternatif olarak piyasaya sürülen ve ozon tabakasına dost olan, iki soğutucu akışkan R-417A ve R-438A termodinamik açıdan incelenmiştir. Yapılan çalışmada, R-22, R-417A ve R-438A soğutucu akışkanlarının performansları karşılaştırılmıştır. Farklı evaporasyon sıcaklıkları için, soğutucu akışkanların performansları termodinamiğin birinci ve ikinci kanunu kullanılarak değerlendirilmiş ve sistemlere ait performans katsayıları hesaplanmıştır. Sonuç olarak incelen 3 akışkan için R22 akışkanına en iyi alternatifin R438A olduğu tespit edilmiştir [4]. La Rocca ve diğ., yaptıkları çalışmada, R413A, R417A, R422A ve R422D'nin R22'nin yerini alması için düşük sıcaklıklı bir soğutma ünitesinde incelemiş, düşük enerji verimliliği ve daha yüksek enerji tüketimi gösteren tüm alternatif akışkanlar için COP'un daha düşük olduğunu bildirmiştir. [5]. Cingiz ve diğ., yaptıkları çalışmada, soğutma sistemlerinde yaygın olarak kullanılan R22 soğutucu akışkanına alternatif ve ozon tabakasına dost R417A, R438A, R422A ve R422D soğutucu akışkanlarının performansları termodinamiğin birinci ve ikinci yasasına göre incelenmiştir. Çalışmanın sonunda, R22 soğutucu akışkanına alternatif olarak geliştirilen R417A, R438A, R422A ve R422D akışkanlarından, R438A akışkanının daha yüksek COP değerlerine sahip olduğu belirlenmiştir [6]. Termal kamera ile yapılan çalışmalar, genelde yalıtım uygulamaları ve enerji tüketiminin belirlenmesi amacıyla kullanılmıştır. Görüntü işleme tekniği gelişmiş ülkelerde uzun yıllardır kullanılmakta olup, uzay araştırmaları, tıp alanında çeşitli hastalıkların tespit edilmesi, tarım ve gıda mühendisliği alanında ürün kalitesinin, makine ve inşaat mühendisliği alanında çeşitli mekanik ve beton malzemelerin özelliklerinin, korozyonlarının belirlenmesinde, ayrıca kalite kontrol alanında yararlanılmıştır. Termal kamera ile görüntü işleme tekniğinin soğutucu akışkan ile sistem performanslarının belirlenmesine yönelik yapılan çalışmalara literatürde rastlanılmamıştır. Görüntü işleme yöntemiyle performans tespiti her ne kadar R22, R417A ve R438A üzerinde gerçekleştirilse de yöntemin uygulama sınırları belirlenip farklı soğutucu akışkan grupları içinde kullanımı genişletilecektir. Çalışan ve diğ., termal kamera görüntülerini, ekipmanların ve cihazların arızalarının giderilmesi, bakımları gibi fonksiyonları icra etmek için kullanmışlardır. Tesisin bakım ve plansız oluşan aksaklıklarına bağlı maliyetler termografi maliyetinden daha pahalı olmaktadır [7]. Weinmann ve diğ., yaptıkları çalışmada, borulardaki ve binalardaki izolasyon kusurlarını belirlemede termal görüntüleri kullanmışlardır. Yapacağımız çalışmada soğutma sistemindeki arızalar, bakım periyotları ve borulardaki izolasyon eksiklikleri ve hatları da rahatlıkla belirlenebilecektir [8]. Katırcıoğlu ve diğ., sunduğu çalışmada, soğutma sistemlerinde termal görüntü analizi ile farklı soğutucu akışkanların uzaktan 
sensörsüz olarak performanslarının karşılaştırılması için, elde edilen termal görüntülerin iyileştirilmesi önerilmiştir [9].

Gerçekleştirilen bu çalışmanın özgün değeri; ticari tip soğutma sistemlerinde, sistem üzerinden alınacak ölçüm değerleri (sıcaklık, basınç vb.) yerine kızılötesi görüntü analizi işleme tekniği kullanılarak farklı soğutucu akışkanların COP değerinin belirlenmesidir. Çalışmada, R22 soğutucu akışkanının alternatifleri, kızılötesi görüntü işleme tekniği açısından incelenmiştir. R22'ye ek olarak R417A ve R438A soğutucu akışkanları ele alınarak, kurulmuş olan soğutma sisteminde yapılan deneyler ve alınan veriler incelenip hesaplamalar yapılmış, buna ek olarak ticari tip soğutma sisteminde kızılötesi görüntüleme analizi hususu da incelenmiştir. Elde edilen sonuçlar soğutma etkinlik katsayısı (COP) performansı açısından değerlendirilmiştir. $\mathrm{Bu}$ çalışma ile ticari tip soğutucular ve endüstriyel tip soğutma sistemleri için performans iyileştirilmesi hedeflenmektedir. Oluşturulacak olan kullanıcı ara yüzü bu alanda çalışacak teknik elemanların kullanımına uygun, basit ve kolay algılanabilir şekilde tasarlanacaktır. Bu sayede, yöntemin yaygınlaştırılması hedeflenmektedir. Başarı durumunda, endüstriyel soğutma sistemlerinde kızılötesi görüntüleme analizinin ele alınması ile teknolojik önemi olan sonuçlar elde edilmesi beklenmektedir. Kızılötesi görüntü verilerinin farklı bir algılama elemanı olarak kullanılması önemli bir yeniliktir. Soğutma sistemini hızlı ve kolay bir yolla izleme kolaylığı getirecektir. Bağlantı olmaksızın termal kamera ve bir bilgisayar, sistemin performansını test etmek için yeterli olacaktır. Uzaktan algılama sayesinde, sisteme yaklaşım açısından iş güvenliğini yükseltme ve kullanım kolaylığı sağlamaktadır. Mevcut araştırmamızda, Bölüm 3.1.'de; öznitelik çıkartım yöntemi ile soğutma sistem performansı belirlenmesi, Bölüm 3.2'de COP yöntemi ile soğutma sistem performansının belirlenmesi, Bölüm 4.'de ise deneysel sonuçların değerlendirilmesi çalışmaları gerçekleştirilmiştir.

\section{R22, R438A ve R417A GAZLARI İLE SOĞUTMA SÍSTEMININ KURULUMU}

\subsection{Kullanılan gazların genel özellikleri}

CFC gazların tüketiminin yasaklanması ile birlikte gelinen noktada ozon tabakasına zarar veren diğer bir gaz grubu olan HCFC gazların da kullanımı önce sınırlandırılmış ardından tamamen yasaklanmıştır. Bu gazlardan en çok kullanılanı R22 gazıdır. R22 gazının alternatifi olarak çeşitli gazlar kullanılmıştır. En sık kullanılanları R404A, R407c ve R410A gazlarıdır. Ancak bu gazların mevcut sistemlerde kullanılmasında bazı problemlerle karşılaşılmaktadır. R22 yerine bu gazlardan herhangi birinin sisteme alınabilmesi için sistem boru hatlarında ve ekipmanlarında değişiklikler yapılması gerekmektedir. Bu durum, uygulamada önemli güçlükler çıkarmaktadır. Bu güçlükleri aşabilmek amacı ile iki yeni alternatif HFC grubu gaz olan R417A ve R438A soğutucu akışkanları piyasaya sürülmüştür. $\mathrm{Bu}$ soğutucu akışkanların ön önemli avantajı; sistem boyutlandırmasında herhangi bir değişikliğe gerek kalmaması ve sadece kurutucu-filtre değişimi ile sisteme uyum sağlayabilmesidir. R417A ve R438A akışkanları HFC karışımlarıdır. Bünyesindeki akışkanların kütlesel miktarları ve ozon yok etme potansiyeli (ODP), küresel isınma potansiyeline (GWP) değerleri Tablo 1'de verilmiştir. Tablo 1'de görüldüğü üzere, R417A ve R438A akışkanlarının ozon tüketim değerleri olmamasına rağmen, küresel 1 sınma potansiyelleri bulunmaktadır. R22 soğutucu akışkanın GWP değeri alternatifi olan akışkanlardan daha düşüktür. Ancak ODP değerlerinin sıfir olması sebebiyle orta vadede R22 ile çalışan sistemlerde kullanılmasının uygun olacağı düşünülebilir.

Tablo 1. Soğutucu Akışkanların Özellikleri (Properties of Refrigerants) [6]

\begin{tabular}{|c|c|c|c|c|c|}
\hline 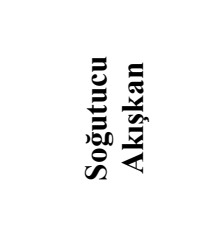 & 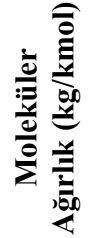 & 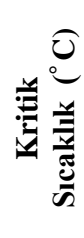 & 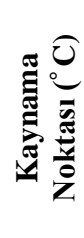 & ิิ & $\sum_{0}^{1}$ \\
\hline $\begin{array}{l}\text { R22 } \\
\text { Bileşim } \\
\text { Saf } \\
\end{array}$ & 86.5 & 96.2 & -40.8 & 0.05 & 1810 \\
\hline $\begin{array}{l}\text { R417A } \\
\text { Bileşim } \\
\text { R125 (\% 46.6) } \\
\text { R134a (\% 50) } \\
\text { R600 (\% 3.4) }\end{array}$ & 106.8 & 87.1 & -39.1 & 0 & 2346 \\
\hline $\begin{array}{l}\text { R438A } \\
\text { Bileşim } \\
\text { R125 (\% 45) } \\
\text { R134a (\% 44.2) } \\
\text { R600 (\% 1.7) } \\
\text { R601a (\% 0.6) } \\
\text { R32 (\% 8.5) }\end{array}$ & 99.1 & 85.3 & -42.3 & 0 & 2264 \\
\hline
\end{tabular}

İçerdiği klor atomları sebebiyle R22, ozon tabakasının tükenmesine yol açmaktadır. Bu yüzden R22 ile çalışan sistemler, uzun vadede (ODP) değeri sıfir olan düşük (GWP) sahip soğutucu akışkanlarla değiştirilmelidirler. Yüksek GWP, yüksek çevresel etki demektir. Sonuç olarak düşük GWP soğutucularının benimsenmesi toplam çevresel etkilerin azaltılması açısından etkili bir çözüm olduğu sonucuna varılmıştır [6]. R417A, R125, R134a ve R600'ün kullanımı kolay, ozon tüketmeyen bir HFC güçlendirme soğutucu karışımıdır. Tipik olarak, direkt genleşmeli sabit iklimlendirme ve orta sicaklıkta soğutma sistemlerinde R22'nin yerine kullanılır. R417A, kompresörün ömrünü uzatabilen R22'den önemli ölçüde daha düşük deşarj sıcaklığına sahiptir. Çoğu sistemde bu ürün gerekli soğutma kapasitesini ve enerji tasarrufu sağlar, ancak bazı sistemler daha düşük kapasitede çalışabilir. Bu soğutucu, hızlı, kolay ve uygun maliyetli iyileştirmeler sağlayan geleneksel ve yeni yağlayıcılarla uyumludur ve tüm soğutucu şarjını çıkarmadan servis sırasında doldurulabilir. R417A bir karışım olduğu için, sistemi şarj ederken, daima bir sıvı olarak silindirden çıkarılmalıdır. Klima ve küçük ticari soğutma uygulamaları için uygun olup $\mathrm{MO} / \mathrm{AB} / \mathrm{POE}$ yağları 
ile uyumludur [10]. R438A, kullanımı kolay, ozona zarar vermeyen HFC soğutucu akışkan karışımıdır. Performans, kapasite, kütle akışı ve basınç karakteristiklerine açısından tüm klima ve chiller uygulamaları için R22'nin yerine alternatif olarak kullanılmak için uygundur. Genleşme valfinin sabit bir deliğe sahip olduğu veya sistemin kapasitesine çok yakın olduğu R422D'ye göre avantajları vardır, R417A'ya göre daha iyi kapasiteye sahiptir. Bu ürün, geleneksel ve yeni yağlayıcılarla uyumludur, hızlı, kolay ve uygun maliyetli bir iyileştirme sağlar ve servis sırasında tüm soğutucu şarjını çıkarmadan tamamlanabilir. R438A bir karışım olduğu için, sistemi şarj ederken daima bir sıvı olarak silindirden çıkarılmalıdır. Ticari klima, ısı pompaları, doğrudan genleşmeli (DX) soğutma sistemleri için uygun olup, MO/AB/POE yağları ile uyumludur [10]. Özellikle R22 ve alternatifleri olarak ele alınan soğutucu akışkanlar düşük sıcaklık uygulamalarındaki ticari tip soğutma sistemleri için uygundur.

\subsection{Soğutma sistemi deney seti kurulumu}

Deney setine ilişkin genel görünüş Şekil 1'de verilmiştir. Üç soğutucu akışkanın enerji değerlendirmesi için kullanılan deneysel sistem, başlangıçta R22 ile çalışmak üzere tasarlanmış buhar sıkıştırmalı soğutma çevrimidir. Tasarlanan deneysel sistemde, R22, R417A ve R438A soğutucu akışkanları kullanılmıştır. Deney sisteminde hermetik pistonlu tip kompresör, hava soğutmalı evaporatör ve kondenser, diştan dengelemeli termostatik genleşme vanası kullanılmış olup, evaporatör yalıtımlı ve sabit hacimli bir kabin içerisine konulmuştur. Test edilen her soğutucu gaz öncelikle sistem vakum edilerek elektronik terazi kullanılarak $900 \mathrm{~g}$ miktarında gaz şarjı yapılmıştır. Deneylerin stabil ve sağlıklı bir ortamda gerçekleştirilebilmesi, farklı gazların performanslarının daha gerçekçi şekilde incelenebilmesi için sistem kapalı bir ortamda, diş sıcaklık sabit olacak bir şekilde imal edilmiştir. Tiç: $22{ }^{0} \mathrm{C}$ (iç-ortam sıcaklığı) olarak kabul edilmiştir. Soğutma sisteminden kızılötesi görüntülerin alınma prosesi Şekil 2'de gösterilmiştir. Önerilen yöntemde kullanılacak bölgeler, numaralandırılmış ve bölge isimleri de yine şekil üzerinde verilmiştir. Tablo 2'de kullanılan soğutma sistem bileşenleri ve özellikleri verilmiştir. Her soğutucu akışkan ile sistem çalışırken termal kamera ile görüntüler, sistem bir saat çalışarak kararlı hale geldikten sonra alınmıştır. Daha sonra verisi alınan soğutucu akışkan sistemden boşaltılıp, sistem vakumlandıktan sonra diğer soğutucu akışkan basılmıştır.

Tablo 2. Soğutma sisteminin bileşenleri ve özellikleri

\begin{tabular}{|l|l|}
\hline Malzemenin adı & Özelliği \\
\hline Hermetik kompresör & $\begin{array}{l}\text { Embraco NEU 6215 GK } \\
\text { Güç: } 1 / 2 \text { HP }\end{array}$ \\
\hline Kondenser hava akışlı & Karyer KT 3/4 HP \\
\hline Evaporatör hava akışlı & Karyer KT 3/4 HP \\
\hline Genleşme vanası & $\begin{array}{l}\text { Dunan TGV, PS 46 bar } \\
\text { Çalışma aralığı: }-40 /+10{ }^{\circ} \mathrm{C}\end{array}$ \\
\hline Termal kamera & $\begin{array}{l}\text { Flir E8-XT 320x240 }(76800 \text { piksel }) \\
-20{ }^{\circ} \mathrm{C}-550{ }^{\circ} \mathrm{C}\end{array}$ \\
\hline Soğutucu akışkan & $\mathrm{R} 22, \mathrm{R} 438 \mathrm{~A}, \mathrm{R} 417 \mathrm{~A}$ \\
\hline
\end{tabular}



Şekil 1. Soğutma sistemi deney seti

Deney sisteminden R22, R438A ve R417A soğutucu akışkanları için alınan infrared görüntüler Şekil 3. a, b ve c' de görülmektedir. Sistemin şematik gösterimi Şekil 4'de verilmiştir. Çalışılan akışkanların performanslarını değerlendirebilmek için, sistemin her ana eleman giriş ve çıkışları (kompresörün giriş-çıkışı, kondenser giriş-çıkışı, termostatik genleşme valfi girişi, evaporatör giriş-çıkışı) ile kompresör, kondenser ve evaporatör yüzeyindeki sicaklıklar, sistem üzerinde belirtilen noktalardan termal kamera ile elde edilerek karşılaştırılmıştır.

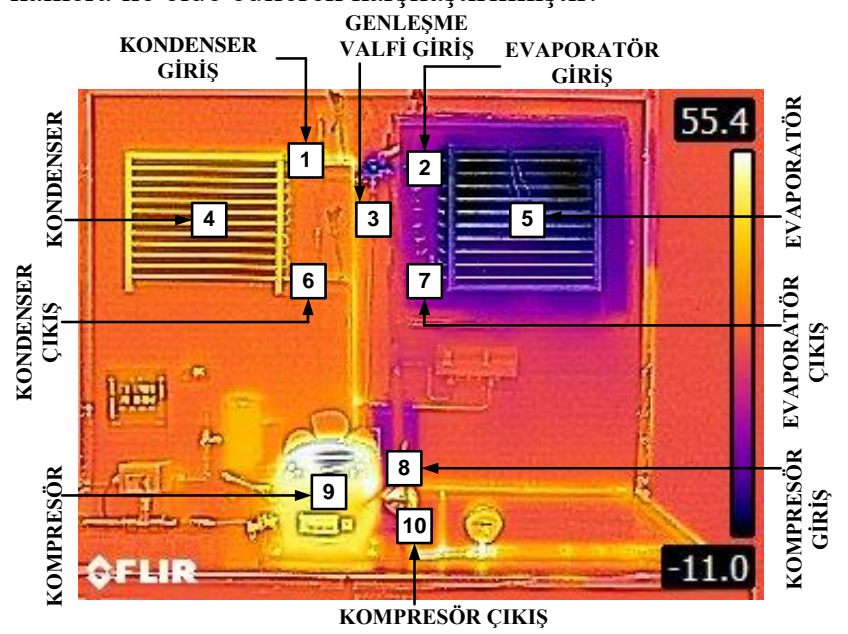

Şekil 2. Soğutma sistemi üzerinden infrared (kızılötesi) görüntü alınan bölgeler 




(a) R22 soğutucu akışkanı infrared görüntüsü

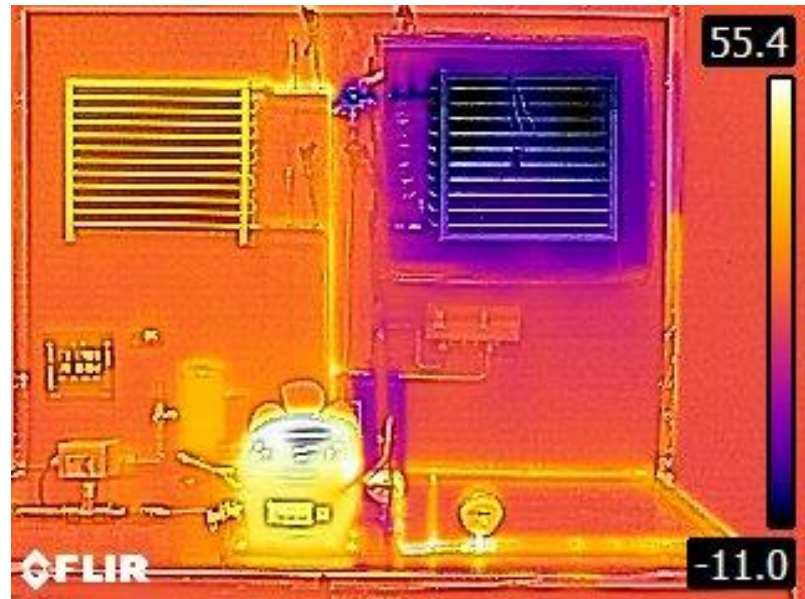

(b) R438A soğutucu akışkanı infrared görüntüsü

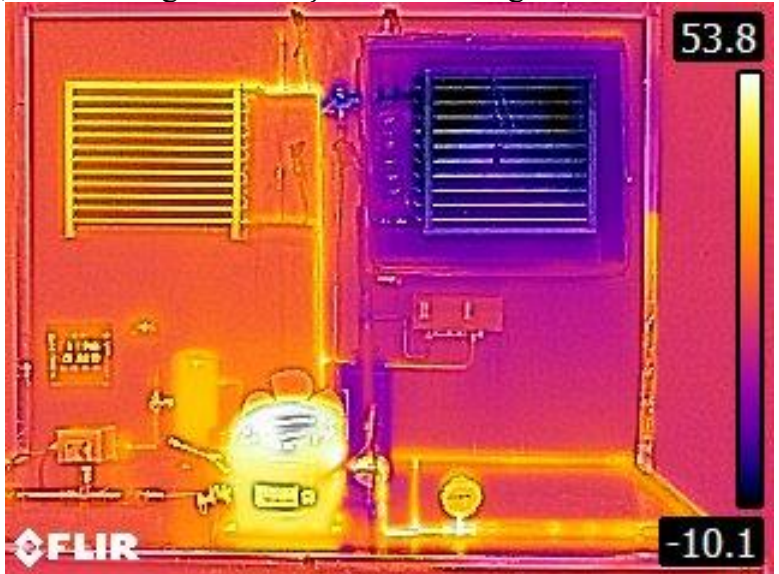

(c) R438A soğutucu akışkanı infrared görüntüsü

Şekil 3. Deney sisteminden alınan soğutucu akışkanlara ait infrared görüntüler

Alternatif gazların kullanımı sistem maliyeti açısından (revizyona ihtiyaç kalmadiğından) daha uygun görülmüştür. $\mathrm{Bu}$ sayede, alternatif akışkanların soğutma etkinlik katsayısı (COP) geleneksel hesaplama yönteminin dişında, termal kamera ile alınan sicaklık verileri kullanılarak, termal görüntü işleme analizi (kompresör, kondenser, evaporatör yüzeylerinden alınacak termal görüntüler ile ana elamanların giriş-çıkışlarından alınacak termal görüntüler) olarak incelenerek, yapılacak soğutucu akışkan dönüşüm işlemlerine ve performanslarına 1 şı tutulması hedeflenilmiştir.

\section{SOĞUTMA SİSTEM PERFORMANSI IÇİN KIZILÖTESİ GÖRÜNTÜ İŞLEME YÖNTEMLERİ}

\section{1. Öznitelik çıkartım yöntemi ile soğutma sistem performansı belirlenmesi}

Üzerinde çalışılan görüntüden öznitelik çıkarma, görüntü analizi ve karar işlemleri için önemli bir adımdır. Görüntülerin içsel içeriğini mümkün olduğunca eksiksiz yansıtabilen ideal özelliklerin nasıl ayıklanacağı hala bilgisayar analiz sistemlerinde zor bir süreçtir. Görüntülerde öznitelik çıkarım yöntemlerini, renk, doku ve şekil olmak üzere üç ana başlık altında toplamak mümkündür. Önerilen çalışmada, kızılötesi görüntü kullanılmasından dolayı renk ve doku üzerine daha fazla yoğunlaşılmıştır. Kızılötesi görüntü üzerinde istenilen bölgelerin seçimi yapıldıktan sonra aşağıda sırası ile verilen öznitelikler elde edilmektedir.

\subsubsection{Standart sapma}

Dijital görüntü işleme uygulamalarında histogram, görüntü seviyesi ile istatistiksel olasılığı arasındaki ilişkiyi göstermek için yaygın olarak kullanılmaktadır [11]. Görüntüdeki her bir pikselin, ortalamadan ne kadar uzakta ya da yakında toplandığı bilgisini veren değere standart sapma denir. Standart sapması küçük olması bir görüntüdeki değerlerin birbirine yakın olduğunu gösterir, büyük olması ise değerlerin birbirinden uzak olduğunu göstermektedir.

$$
\sigma_{g}=\sqrt{\sum_{g=0}^{L-1}(g-\bar{g})^{2} P(g)}
$$

Eşitlik 1'de verildiği gibi $\mathrm{P}(\mathrm{g})$ görüntünün birinci dereceden histogram olasılığı olup, şu şekilde tanımlanır:

$$
P(g)=\frac{N(g)}{M}
$$

Burada M görüntüde ki toplam piksel sayısını, N (g) g renk tonunda ki piksel sayısını ifade etmektedir. Eşitlik 1'de verilen $\bar{g}$ görüntünün ortalama değeri olup Eşitlik 3'de verildiği gibi bulunur [12].

$$
\bar{g}=\sum_{g=0}^{L-1} g P(g)
$$

\subsubsection{Entropi}

Entropi bir değişkendeki belirsizliği ölçmek için kullanılır. Değişkenin bütün değerleri birbirine eşit olduğunda belirsizlik yoktur ve entropi değeri sıfır olur. Ancak değişken tamamen birbirinden farklı değerler alıyorsa entropi maksimum değerine ulaşır [13]. 


$$
\text { Entropi }=-\sum_{g=0}^{L-1} P(g) \log _{2}(P(g))
$$

\subsubsection{Kontrast}

Görüntünün en açık ve en koyu bölgeleri arasındaki farktır. Yüksek kontrastlı görüntü hem 1şığın çok güçlü olduğu bölgelere hem de çok koyu gölgelik alanlara sahiptir. Küresel kontrast ölçüsü olarak Michelson eşitliği kullanılmış olup Eşitlik 5'de verildiği gibi ifade edilmektedir [14].

$$
C=\frac{L_{\max }-L_{\min }}{L_{\max }+L_{\min }}
$$

Eşitlikteki $C$ global kontrast değerini temsil ederken maksimum parlaklık $L_{\max }$ ve minimum parlaklık $L_{\min }$ ile gösterilmiştir.

\subsection{4. Çarpıklık}

Renk bilgisi kızılötesi görüntülerinin en önemli özelliklerinden biridir. Seçilen bölge alanı belirlendikten sonra çarpıklık değeri Eşitlik 6'da verilmiştir. Seçilen bölge içerisinde piksel renk değerleri simetrik değildirler. Bundan dolayı, çarpıklık, kullanılan ortalamanın simetrik özelliğinden ne kadar uzak olabileceğini göstermektedir.

$$
\gamma_{i}=\left(\frac{1}{N} \sum_{j=1}^{N}\left(f_{i j}-\mu_{i}\right)^{3}\right)^{\frac{1}{3}}
$$

Eşitlik 6'da verildiği gibi $f_{i j}$ değeri $j$. görüntü pikselinin $i$. kanaldaki renk değerini, $\mu_{i} i$. kanalın renk ortalama değerini, $N$ ise görüntüde ki toplam piksel sayısını temsil etmektedir. $\gamma_{i}$ ise her bir kanaldaki çarpıklık değeridir.

\subsubsection{Maksimum ve minimum yüzey sıcaklık değeri}

Üzerinde çalışılmak için kesilen bölgenin maksimum, minimum ve ortalama sıcaklık değerleri analiz için gerekli öznitelik verilerini oluşturmaktadır. Bunun için Eşitlik 7'de verildiği gibi maksimum ve minimum sicaklık verilerinin elde ediliş yöntemleri sunulmuştur.

$$
\begin{aligned}
& T_{\text {max }}=\max \left(T_{\text {low }}+\left(T_{\text {high }}-T_{\text {low }}\right) * T_{-} I\right) \\
& T_{\text {min }}=\min \left(T_{\text {low }}+\left(T_{\text {high }}-T_{\text {low }}\right) * T_{-} I\right)
\end{aligned}
$$

Eşitlik 7' de verildiği gibi $T_{-} I$, renkli kızılötesi görüntünün gri termal görüntüye dönüştürülerek elde edilen giriş görüntüsünü, $T_{\text {low }}$ ve $T_{\text {high }}$ sicaklık barının alt ve üst değerlerini göstermektedir.

\subsubsection{Ortalama yüzey sıcaklık değeri}

Belirlenen bölgenin kızılötesi görüntüsünde yer alan sıcaklık değerlerinin ortalama değeri Eşitlik 8'de verilmiştir.

$$
T_{a v}=\frac{\sum_{i=1}^{M} \sum_{j=1}^{N} T_{\text {low }}+\left(T_{\text {high }}-T_{\text {low }}\right) * T_{-} I}{M * N}
$$

Eşitlik 8 'de verilen, $M$ ve $N$ kesilen bölgenin boyut bilgileridir.

\subsubsection{En yoğun yüzey sıcaklık değeri}

Belirlenen bölgenin kızılötesi görüntüsünde en çok karşılaşılan sıcaklık değerini tespit etmek için Algoritma 1 kullanılmıştır.

Algoritma 1. En yoğun yüzey sıcaklık değer belirleme kodu. Adım 1. Her bir piksele karşılık gelen sıcaklık değerini bul. Adım 2. En yoğun yüzey sıcaklık değerini bulma

$$
\begin{aligned}
& \text { for } i=1 \text { :satir } \\
& \text { for } \mathrm{j}=1 \text { :sütün } \\
& \text { değer }=T \quad I(i, j) \text {; } \\
& \text { end } \\
& \text { frekans }(\overline{\text { değer}})=\text { frekans }(\text { değer })+1 \text {; } \\
& \text { end }
\end{aligned}
$$

Adım 3. En yoğun sıcaklık değerini göster

Tyoğun $=\operatorname{Max}($ frekans $($ değer $))$;

\subsection{COP yöntemi ile soğutma sistem performansı}

Buhar sıkıştırmalı soğutma sistemleri, düşük sıcaklıktaki bir ortamdan 1sıyı çekerek yüksek sıcaklıktaki ortama aktaran ve böylece bulunduğu ortamı soğutan sistemlerdir. Sistemde, çevrim esnasında soğutucu akışkan çeşitli termodinamik işlemler geçirerek soğutma işini gerçekleştirilmektedir. Şekil 4'de görülen tek kademeli bir buhar sıkıştırmalı soğutma sisteminin temel elemanları, kompresör, yoğuşturucu (kondenser), kısılma vanası ve buharlaştırıcıdan (evaporatör) oluşmaktadır. $\mathrm{Bu}$ çalışmada, sistemin performans analizi, termodinamiğin birinci kanununa göre yürütülmüştür. Soğutma sistemine ait birinci kanun analizinde, kondenser, kompresör ve evaporatör kapasiteleri, Şekil 4 üzerindeki çevrim noktaları göz önüne alınarak, sırasıyla aşağıdaki eşitlikler aracılığı ile hesaplanmaktadır [4].

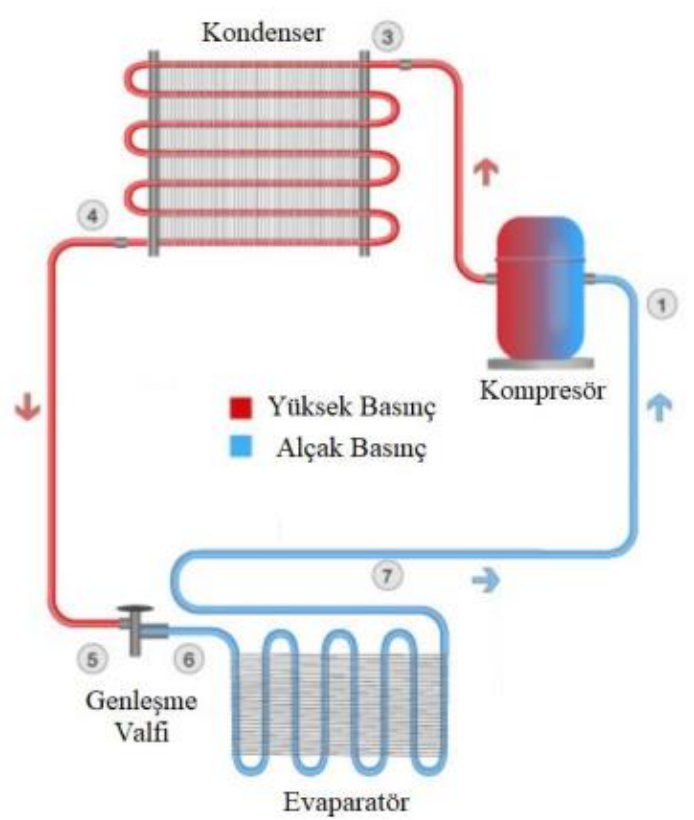

Şekil 4. Bir buhar sıkıştırmalı soğutma çevriminin şeması ve temel elemanları 


$$
\begin{aligned}
& \dot{Q}_{\text {kond }}=\dot{m}_{s a} \cdot\left(h_{3}-h_{4}\right) \\
& \dot{Q}_{\text {evap }}=\dot{m}_{s a} \cdot\left(h_{7}-h_{6}\right) \\
& \dot{W}_{\text {komp }}=\dot{m}_{s a} \cdot\left(h_{1}-h_{2}\right)
\end{aligned}
$$

Kompresöre uygulanan elektrik gücü ise kompresör gücünün, elektrik ve mekanik verimlere bölünmesi ile bulunmaktadır.

$$
\dot{W}_{\text {komp }, e l}=\frac{\dot{W}_{\text {komp }}}{\eta_{e l} X \eta_{m e k}}
$$

Bir soğutma sisteminin performansı COP, soğutma etkinlik katsayısı ile değerlendirilir. İdeal buhar sıkıştırmalı bir soğutma çevrimi için soğutma etkinlik katsayısı Eşitlik 13'de verilen denklem ile tanımlanmaktadır.

$$
C O P=\frac{\dot{Q}_{\text {evap }}}{\dot{W}_{\text {komp }, e l}}
$$

COP, soğutma sisteminin veriminin, sıkıștırma işleminde harcanan enerjinin, buharlaşmada soğurulan enerjiye oranı ile belirlenen miktarı veya ölçüsüdür. Sıkıştırma işleminde ne kadar az enerji harcanırsa, soğutma sisteminin etkinlik katsayısı COP, o kadar büyük olur. $\mathrm{Bu}$ yüzden, diğer özellikleri ve faktörleri eşit olan soğutucular arasından, en yüksek COP'a sahip olan soğutucu seçilmelidir. COP değerinin hesaplanması, birinci kanun analizinde, gaz soğutucusu sıcaklığı, evaporatör sıcaklığı, aşırı kızdırma sıcaklığı ve kompresör verimi değişimleri için gereklidir. Yukarıda verilen eşitliklerde (Eşitlik 9-13), $h$ ilgili referans numarası ile gösterilen entalpi değerini $(\mathrm{kJ} / \mathrm{kg})$ göstermektedir. $\dot{\mathrm{m}}_{\mathrm{sa}}$ soğutucu akışkan debisini $(\mathrm{kg} / \mathrm{s})$ belirtmektedir. Eşitlik 10, 12 ve 13' de verilen termodinamik denklemlerinden esinlenilerek kızılötesi görüntü işleme yöntemlerinde kullanılabilecek soğutma sistem performans katsayısı önerilmiştir. Önerilen $C O P_{k o ̈ g i}$ katsayısı Eşitlik 14 'de verildiği gibi, sistemin yüzey sicaklık bilgilerinin kullanımını esas almaktadır. Buradaki $C O P_{k o ̈ g i}$, kızılötesi görüntü işleme (kögi) olarak kısaltma kullanılmıştır.

$$
C O P_{k o ̈ g i}=\frac{\left(K o m p_{\text {çıkış }}-K o m p_{\text {giriş }}\right)}{\left(E v a p_{\text {çıkış }}-E v a p_{\text {giriş }}\right)}
$$


giriş ve çıkış yüzeysel sicaklık değerlerini, Evap çıkıș ve Evap $_{\text {giriș }}$ ise evaparatörün giriş ve çıkış yüzey sıcaklık değerlerini temsil etmektedir. Önerilen çalışmada, R22, R438A ve R417A gazlarının kızılötesi görüntüleri üzerinde yukarıda ki dört bölge seçimi yapıldıktan sonra, elde edilen değerler Eşitlik 14'e uygulanmaktadır. Seçilen bölgelerde ortalama sıcaklık değeri esas alınmıștır.

\section{DENEYSEL SONUÇLAR}

\section{1. Öznitelik çıartım yöntemi ile soğutma sistem performans deneysel sonuçları}

MATLAB (MATrix LABoratory) 1985 yılında C.B Moler tarafindan matematik ortamında kullanılmak üzere geliştirilmiş olup, sayısal hesaplama, veri çözümleri ve grafik işlemlerinde kullanılabilecek genel amaçlı olmakla beraber, özel amaçlı modüler paketlere de sahip etkileşimli bir paket programlama dilidir [15]. MATLAB 'da problemler, komut satırında çalışan programlar yazarak çözülebileceği gibi, MATLAB GUI (Graphical User Interfaces) geliştirme aracını kullanarak, formlar ve butonlar gibi nesnelerden oluşan görsel yazılımlar da oluşturulabilmektedir [16, 17]. Öznitelik Çıkartım Yöntemi (ÖÇY) olarak adlandırılacak olup, ara yüzü Şekil 5'de verilmiştir. Üzerinde çalışılan soğutma gazının kızılötesi görüntüsü yüklenerek, başlanmaktadır. Kızılötesi görüntüsünde yer alan sıcaklık bar göstergesinin alt ve üst sıcaklık değerleri girildikten sonra "Kes" butonuna basılır. "Kes" butonuna basılmasıyla görüntünün sol üst köşesi ve sağ alt köşesinden istenilen koordinat noktaları girilmektedir. Böylece deney setinin arka plan kısımları, sıcaklık bar göstergesi gibi istenilmeyen bölgeler kesilerek atılmaktadır. Ayrıca sözde renkli kızılötesi görüntü üzerinden her bir piksel için sıcaklık atama hesaplamaları bu bölümde yapılmaktadır. Bu işlemden sonra, kullanıcıdan kesilen görüntüyü kaç alt bölgeye ayırması gerektiği sorulur ve bunun için satır ve sütün bilgileri girilmektedir. Çalışma da bütün görüntüler 20x20 olmak üzere 400 alt bölge oluşturularak analiz ișlemi gerçekleștirilmiștir. "Bölütleme" butonuna basılmasıyla görüntü alt bölgeleri kırmızı çizgi ile belirlenmiş olarak ara yüzde, orta bölümde güncellenmektedir. İşlem hızını artırmak ve kullanıcının istediği bölgelere yoğunlaşmak için kullanıcıdan hangi bölgeleri istiyor ise o bölge numaraları girilerek, "Analize Başla" butonuna basılmaktadır. Seçilen bölgeler için standart sapma, entropi, kontrast, çarpıklık, maksimum, minimum, ortalama ve en yoğun sicaklık öznitelik verileri elde edilmektedir. Ayrıca bölgelerin görüntüleri ve öznitelik eğrileri ara yüzün sol tarafinda oluşmaktadır. ÖÇY, R22, R438A ve R417A gazları için 3 kızılötesi test görüntülerinde çalıştırılmıştır. Her bir test görüntüsü için 10 bölge belirlenerek 8 öznitelik elde edilmiştir. Tablo 3'ün sayısal sonuçlarına bakıldığında, gazların performans sonuçları için kesin bir sonuç cümlesi söylemek veya karşılaştırma yapmak zordur. Bunun için Tablo 3'de yer alan üç gazın öznitelik verileri ve belirlenen bölgeler için karşılaştırmalı kutu grafik çalışmaları gerçekleştirilmiştir. Kutu grafikleri değişkenin dağılım şeklini, merkez eğilimini ve yayılım düzeyini görmek ve bir değişkenin farklı kategorilerini birbiriyle karşılaştırmak için kullanışlı bir grafik türüdür. Bir veri setinin en küçük değer, alt çeyrek, ortanca, üst çeyrek ve en büyük değer olmak üzere beș sayılı özetini göstermektedir.

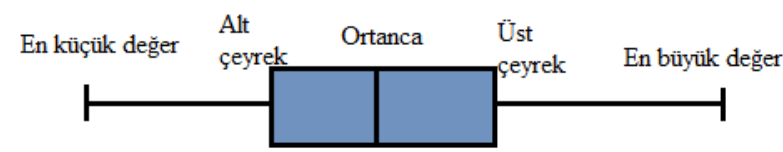

Şekil 6. Kutu grafiği ve bölümleri

Şekil 6'da görüldüğü gibi birinci çeyrekten üçüncü çeyreğe bir kutu çizilmektedir. Kutunun uzunluğu verilerin orta bölümlerde yayılma özelliğini vermektedir. Ortanca değer kutudan düşey bir çizgi ile geçmektedir. Verinin uç değerleri kolaylıkla görülmekte olup kutudan bu noktalara çizilen çizgi ile gösterilmektedir. Şekil 7'de görüldüğü gibi ÖÇY de 
belirlenen bölgeler karşılaştırmalı olarak verilmiştir. Her bir bölge görüntüsünün bütün gazlarda birbirlerine çok benzer olmaları yapılan görüntü alma ve bölgelerin elde edilme süreçlerinin hassas ve doğru yapıldığını göstermektedir. Şekil 7.'de verilen görsel karşılaştırma, aynı şekilde Tablo 3.'de verildiği üzere sayısal karşılaştırmada olduğu gibi, performans karşılaştırmaları veya benzerlikleri için bilimsel bir sonuç elde etme yönünden yeterli değildir. Bunun için Şekil 7. ve Tablo 3. gazların performans karşılaştırmalarının görüntülerden alınan verilerin analiz edilerek gerçekleştirilebileceği sonucunu vermektedir.

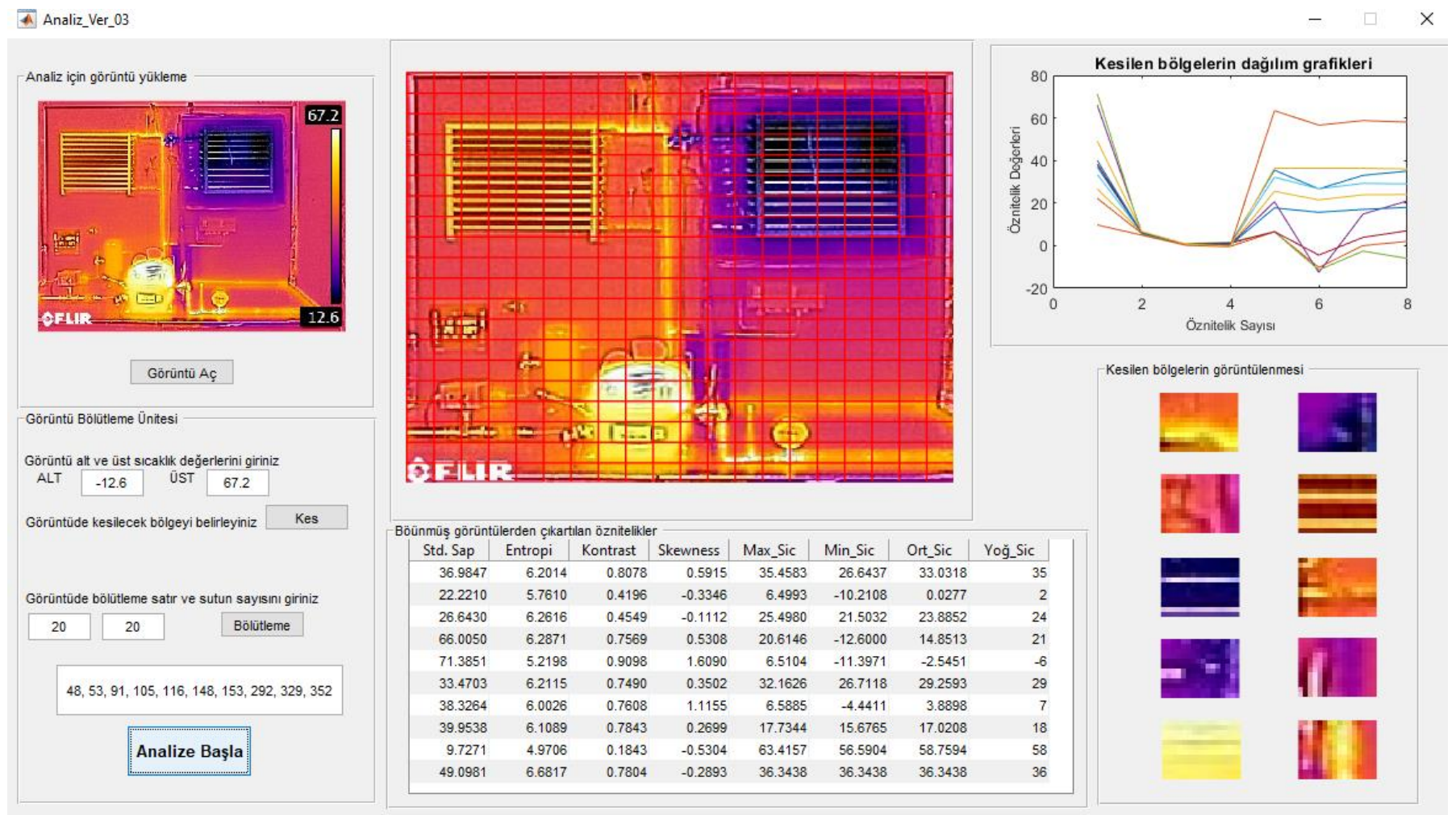

Şekil 5. Matlab GUI öznitelik çıkartım yöntemi ara yüzü

Tablo 3. Kullanılan gazların öznitelik verileri

\begin{tabular}{|c|c|c|c|c|c|c|c|c|c|}
\hline $\begin{array}{c}\text { Kullanılan } \\
\text { Gaz }\end{array}$ & $\begin{array}{c}\text { Bölge } \\
\text { No }\end{array}$ & $\begin{array}{c}\text { Standart } \\
\text { Sapma }\end{array}$ & Entropi & Kontrast & Çarpıklık & $\begin{array}{c}\text { Maksimum } \\
\text { Sicaklik } \\
\left({ }^{\circ} \mathrm{C}\right)\end{array}$ & $\begin{array}{c}\text { Minimum } \\
\text { Sicaklık } \\
\left({ }^{\circ} \mathrm{C}\right)\end{array}$ & $\begin{array}{c}\text { Ortalama } \\
\text { Sicaklik } \\
\left({ }^{\circ} \mathrm{C}\right)\end{array}$ & $\begin{array}{l}\text { Yoğun } \\
\text { Sicaklık } \\
\left({ }^{\circ} \mathrm{C}\right)\end{array}$ \\
\hline \multirow{10}{*}{$\stackrel{\widetilde{\Xi}}{\approx}$} & 1 & 36,6833 & 6,1615 & 0,8078 & 0,5668 & 35,3073 & 26,6688 & 33,1339 & 35 \\
\hline & 2 & 22,0723 & 5,6714 & 0,4157 & $-0,4939$ & 6,4720 & $-8,3904$ & 0,9701 & 3 \\
\hline & 3 & 26,8951 & 6,1363 & 0,4824 & $-0,2508$ & 25,3572 & 24,5039 & 24,8075 & 25 \\
\hline & 4 & 66,0363 & 6,2439 & 0,7529 & 0,5303 & 20,6042 & $-12,6000$ & 15,4080 & 21 \\
\hline & 5 & 72,5085 & 5,3650 & 0,9098 & 1,4670 & 8,0104 & $-11,3111$ & $-1,7654$ & 8 \\
\hline & 6 & 33,3421 & 6,1935 & 0,7373 & 0,3995 & 32,4176 & 26,5357 & 28,8928 & 29 \\
\hline & 7 & 39,0315 & 5,7217 & 0,7333 & 1,3231 & 6,3277 & $-4,4732$ & 3,5585 & 6 \\
\hline & 8 & 41,1147 & 5,9001 & 0,7569 & 0,3608 & 18,0521 & 15,5177 & 17,2708 & 18 \\
\hline & 9 & 9,7317 & 5,0100 & 0,1843 & $-0,5107$ & 63,2381 & 56,5474 & 58,8153 & 58 \\
\hline & 10 & 53,2030 & 6,7760 & 0,7882 & $-0,1830$ & 36,2240 & 36,2240 & 36,2240 & 36 \\
\hline
\end{tabular}




\begin{tabular}{|c|c|c|c|c|c|c|c|c|c|}
\hline \multirow{10}{*}{$\begin{array}{l}\underset{\infty}{\mathscr{N}} \\
\stackrel{m}{ \pm}\end{array}$} & 1 & 38,0885 & 6,4576 & 0,7098 & $-0,1814$ & 32,5208 & 25,7958 & 31,6172 & 33 \\
\hline & 2 & 27,5112 & 5,7803 & 0,6235 & 0,0182 & 9,4731 & $-9,4249$ & $-0,0100$ & 2 \\
\hline & 3 & 26,2515 & 6,1035 & 0,5804 & 0,0342 & 26,4944 & 19,6666 & 21,4126 & 20 \\
\hline & 4 & 80,8172 & 5,3689 & 0,8392 & 0,6535 & 16,3646 & $-11,0000$ & 8,7909 & 16 \\
\hline & 5 & 62,4135 & 5,7927 & 0,8157 & 1,3845 & 5,1563 & $-8,0589$ & $-1,4210$ & 5 \\
\hline & 6 & 34,1888 & 6,1954 & 0,7176 & $-0,3053$ & 32,4003 & 25,5389 & 27,1124 & 26 \\
\hline & 7 & 42,9209 & 5,8744 & 0,7569 & 1,2369 & 9,3270 & $-4,4058$ & 6,0444 & 7 \\
\hline & 8 & 39,6146 & 5,2852 & 0,7465 & 0,3512 & 18,0402 & 13,2177 & 17,2452 & 18 \\
\hline & 9 & 24,7249 & 5,1750 & 0,5059 & $-2,1834$ & 48,4942 & 45,4583 & 46,1272 & 45 \\
\hline & 10 & 47,9484 & 6,7031 & 0,7804 & 0,0820 & 28,3229 & 19,5795 & 27,2729 & 28 \\
\hline \multirow{10}{*}{$\frac{\nwarrow}{\Xi}$} & 1 & 34,6510 & 6,1051 & 0,6667 & 0,6263 & 29,9792 & 24,5244 & 28,7198 & 30 \\
\hline & 2 & 18,0584 & 5,3165 & 0,3569 & $-0,2330$ & 9,4902 & $-5,3404$ & 3,9494 & 4 \\
\hline & 3 & 26,0992 & 6,1373 & 0,4078 & $-0,0354$ & 20,4905 & 12,5472 & 17,4716 & 17 \\
\hline & 4 & 66,9122 & 6,3828 & 0,7725 & 0,1575 & 23,1719 & $-10,1000$ & 18,4552 & 23 \\
\hline & 5 & 46,9458 & 5,4537 & 0,7176 & 1,4172 & 2,5052 & $-6,9146$ & $-1,3101$ & -1 \\
\hline & 6 & 32,6906 & 6,1934 & 0,7333 & 0,4949 & 28,1146 & 25,5027 & 27,4975 & 28 \\
\hline & 7 & 35,1863 & 5,8219 & 0,7529 & 1,5207 & 5,2708 & $-1,8404$ & 3,2072 & 5 \\
\hline & 8 & 29,0314 & 5,7603 & 0,6196 & 0,2096 & 13,3907 & 8,9304 & 11,7171 & 13 \\
\hline & 9 & 11,8201 & 4,9199 & 0,2706 & $-0,5267$ & 51,4177 & 47,5103 & 48,2992 & 48 \\
\hline & 10 & 54,9558 & 6,7278 & 0,7686 & $-0,0582$ & 26,8125 & 26,8125 & 26,8125 & 27 \\
\hline
\end{tabular}

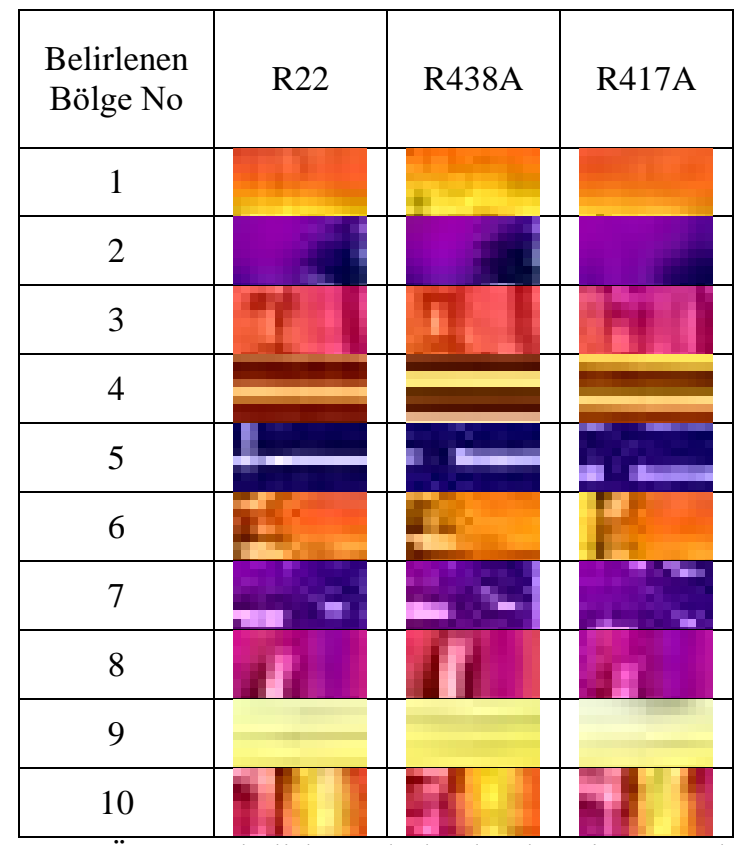

Şekil 7. Üç gazın belirlenen bölge kızılötesi görüntüleri 
Şekil 8 'de kullanılan 3 gazın 8 öznitelik değeri yönünden karşılaştırmalı kutu grafiklerine yer verilmiştir. Şekil 8 a, c, e, f ve g ortalama yönünden, Şekil 8 b, d, e, f ve h alt ve üst çeyrek yönünden, Şekil $8 \mathrm{c}, \mathrm{d}, \mathrm{g}$ ve h üst limit yönünden, Şekil 8 d, e, f, g ve h alt limit yönünden R22 ve R438A birbirlerine çok yakındır. Özellikle standart sapma, entropi, maksimum, minimum ve ortalama sicaklık öznitelik verileri R22 ve R438A gazlarının birbirlerine benzer olduğunu göstermektedir. Ayrıca çarpıklık ve en yoğun sıcaklık öznitelik değerleri bakımından R438A ile R417A birbirine benzer, kontrast öznitelik karşılaştırmasında R417A ile R22 birbirine benzer çıkmıştır. Sonuç olarak, öznitelik veri karşılaştırmasında R22 gazı performans sonuçları R438A'ya daha yakındır. ÖÇY'nin uygunluğunu ve performansını daha iyi test etmek amaciyla bölgelerin üç gaz için karşılaştırılması Şekil 9'da yapılmıştır.

Grafikler incelendiğinde R22 gaz sonuçlarının 2, 4, 5, 7 ve 9. bölgelerde daha normal bir dağılıma sahip olduğu, buna karşın 1, 3 ve 6 . bölgelerde görüldüğü gibi, R438A gazının öznitelik değerlerinin daha yüksek rakamlarda toplandığ1 tespit edilmiştir. Yani 5 bölge için R22, 3 bölge için R438A gazının daha başarılı oldukları görülmektedir. Şekil 9 1, 2, 3, 4, 6 ve 8. bölgeleri için R22 ve R438A gazları, Şekil 97 ve 9. bölgeleri için ise R22 ve R417A gazları birbirlerine yakın performans göstermişlerdir. Ayrıca Şekil 9 10. bölge için R438A ve R417A gazları benzer ve Şekil 9 5. bölge için ise üç gazda birbirine yakın performans göstermişlerdir. Şekil 9'da ki ÖÇY 'nin bölgesel görsel sonuçlarına göre, sirasiyla R22, R438A ve R417A performans siralamas1 yapılabilir. Ek olarak bölgesel performans benzerliğinde R22 gazına en yakın gaz R438A çıkmıştır.

\subsection{COP yöntemi ile soğutma sistem performans deneysel sonuçları}

COP yöntemi ile soğutma sistem performans ara yüzü Şekil 10'da verilmiştir. ÖÇY yönteminde olduğu gibi COP yöntemin kızılötesi görüntülerin analiz işlemine sokulması için ön hazırlık çalışmaları yer almaktadır. COP yönteminde evaporatör giriş ve çıkış ile kompresör giriş ve çıkış bölgeleri için bölümlenmiş görüntü üzerinden bölge numaraları girilmelidir. "Analize Başla" butonuna basıldıktan sonra, ara yüzün sol alt tarafında ilgili gazın COP değeri yazılmaktadır. Ayrıca üzerinde çalışılan dört bölge görüntüsü ve hesaplamaya katılan sıcaklık değerleri tablo halinde sol kısımda oluşmaktadır.

Tablo 4. Kullanılan gazların COP sonuçları

\begin{tabular}{|c|c|c|c|}
\hline Gaz & Bölge & Sicaklık $\left({ }^{\circ} \mathrm{C}\right)$ & $\mathrm{COP}$ \\
\hline \multirow{4}{*}{$\mathrm{R} 22$} & Evaporatör Giriş & $-2,3791$ & \multirow{4}{*}{3,6231} \\
\hline & Evaporatör Çıkış & 1,9503 & \\
\hline & Kompresör Giriş & 18,7736 & \\
\hline & Kompresör Çıkış & 34,4593 & \\
\hline \multirow{4}{*}{$\mathrm{R} 438 \mathrm{~A}$} & Evaporatör Giriş & $-2,4081$ & \multirow{4}{*}{3,5653} \\
\hline & Evaporatör Çık1ş & 1,1318 & \\
\hline & Kompresör Giriş & 17,4287 & \\
\hline & Kompresör Çıkış & 30,0493 & \\
\hline \multirow{4}{*}{ R417A } & Evaporatör Giriş & $-3,2319$ & \multirow{4}{*}{2,9617} \\
\hline & Evaporatör Çıkış & 1,1500 & \\
\hline & Kompresör Giriş & 12,4807 & \\
\hline & Kompresör Çık1ş & 25,4585 & \\
\hline
\end{tabular}

COP, R22, R438A ve R417A gazları için 3 kızılötesi test görüntülerinde çalıştırılmıştır. Her bir test görüntüsü için 4 bölge üzerinden COP değeri hesaplanmıştır. Tablo 4'ün sayısal sonuçlarına bakıldığında, üç gazda birbirine yakın performans göstermişlerdir. COP'un sayısal sonuçlarına göre, sirasiyla R22, R438A ve R417A performans sıralamas1 yapılabilir. Ek olarak bölgesel performans benzerliğinde R22 gazına en yakın gaz R438A çıkmıştır. 


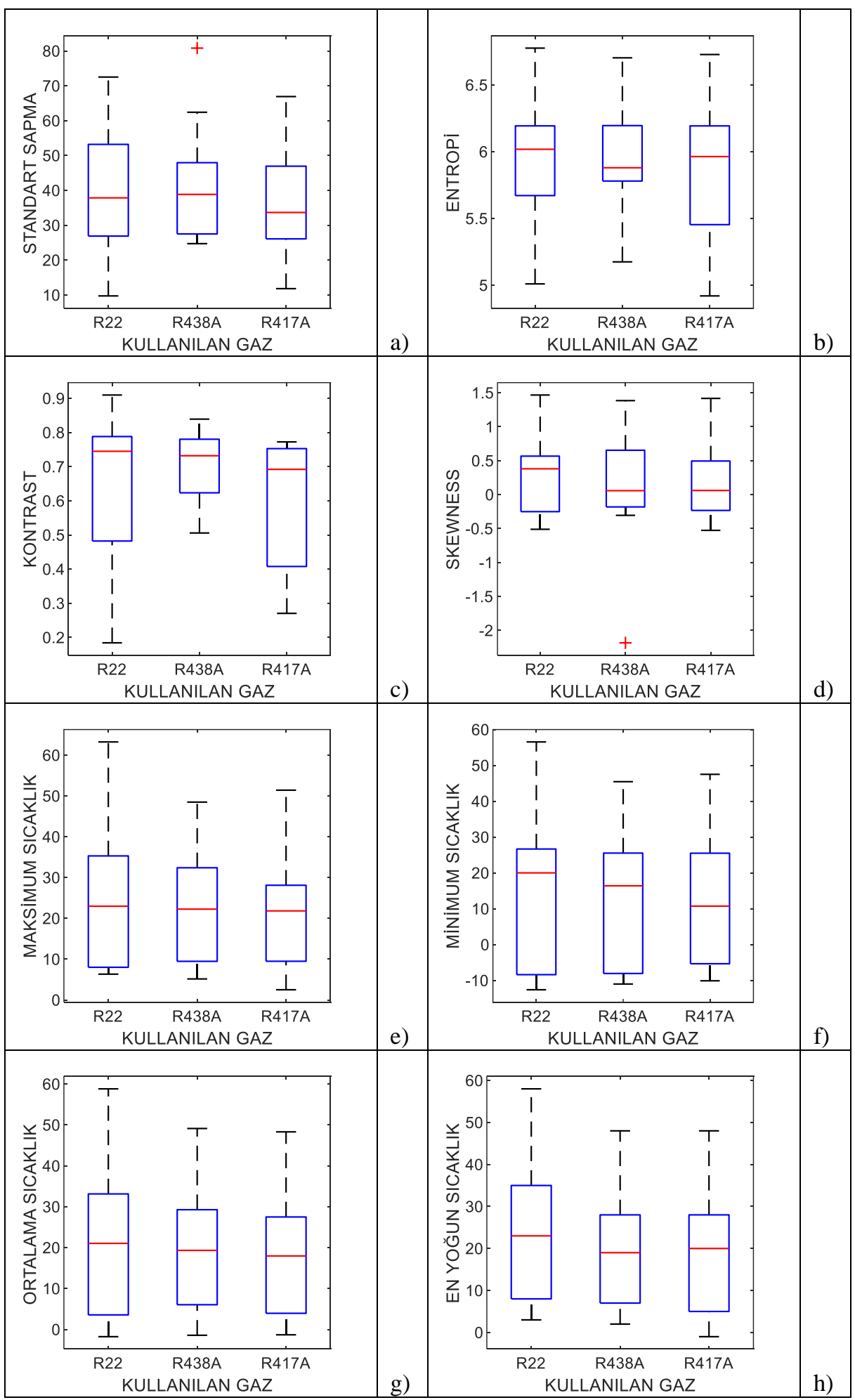

Şekil 8. Üç gazın öznitelik verileri yönünden karşılaştırmalı kutu grafikleri 




Şekil 9. Üç gazın belirlenen bölge verileri yönünden karşılaştırmalı kutu grafikleri 


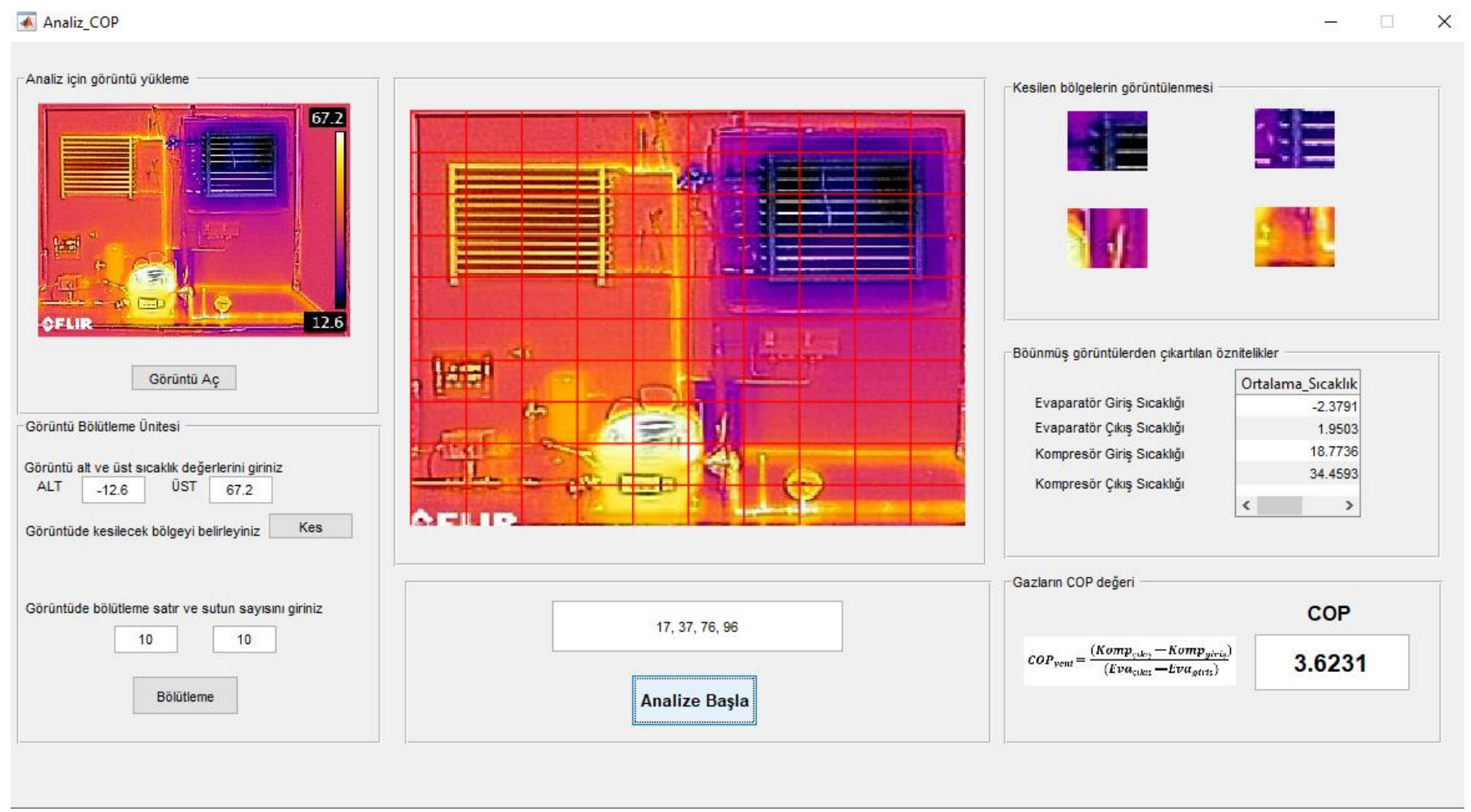

Şekil 10. Matlab GUI öznitelik çıkartım yöntemi ara yüzü

\section{SONUÇ}

$\mathrm{Bu}$ çalışmada, R22 akışkanına alternatif olan ve ozon tabakasına dost R417A ve R438A akışkanlarının ticari soğutma sistemlerine yönelik performans analizi önerilmiştir. Matlab GUI ara yüzü ve kızılötesi görüntüleme kullanılarak öznitelik veri elde edinimi ve yeni bir COP soğutma etkinlik katsayısı olmak üzere iki yöntem kullanılmıştır. Yapılan deneyler sonucunda, kızılötesi görüntüleme sayesinde soğutma sisteminin başarılı bir şekilde uzaktan performans analizinin gerçekleştirilebileceği ispatlanmıştır. Öznitelik veri elde ediniminde, standart sapma, entropi, maksimum, minimum ve ortalama sicaklık değerleri R22 ve R438A gazlarının birbirlerine benzer olduğunu göstermektedir. Ayrıca yeni COP'un sayısal sonuçlarına göre, sırasıyla R22 $(3,6231)$, R438A $(3,5653)$ ve R417A (2,9617) performans sıralaması yapılmıştır. Geliştirilen kızı̈ötesi görüntü işleme ile performans testi uygulamasında çalıştırıla bilirliği ortaya konmuştur. Yapılan çalışmada kullanılan kızılötesi görüntüleme ile sensor montajı, maliyeti ve kablolama problemi ortadan kaldırılmış, ara yüz özelliği ile daha görsel hale getirilmiştir. Sistem için geliştirilen yazılım, kullanıcı için kolay programlanabilir özellikte olup, eş zamanlı kayıt ve grafik çizebilme özelliklerine sahiptir. Çalışmanın sonunda, R22 soğutucu akışkanına alternatif olarak geliştirilen R417A ve R438A akışkanlarından, R438A akışkanının daha yüksek COP değerine sahip olduğu görülmüştür. İncelen 3 akışkan için R22 akışkanına en iyi alternatifin R438A olduğu tespit edilmiştir. Ticari tip soğutma sistemlerinde kullanılacak en uygun alternatif soğutucu akışkan belirlenmiştir. Sensörsüz uzaktan algılamanın bu sistemlere uygulanması ve sistem performansı, insan gücü maliyetini ile zaman tasarrufunu elde edilerek sağlanmıştır.

\section{TEŞEKKÜR}

Çalışmamız Düzce Üniversitesi Bilimsel Araştırma Projeleri (BAP) Birimi (No: 2019.21.02.983) tarafindan desteklenmiştir.

\section{KAYNAKÇA}

[1]. C. C. Allgood ve C. C. Lawson, "Performance of R438A in R-22 refrigeration and air conditioning systems,", International Refrigeration and Air Conditioning Conference at Purdue, Indiana, 2010.

[2]. M. Baraz, "Alternatif soğutkan kullanılan doğrudan genleşmeli soğutma sistemlerinde evaporatör ve kondenser kapasitesine etki eden parametrelerin incelenmesi,", Doktora Tezi, 2011.

[3]. Bock Compressor, "Alternative RefrigerantsInformation on use of R22," 7 Nisan 2020. URL:http://www.bock.de/media/files/PDF/Produktinformat ionen/96151_Alternative-refrigerants_R22_Gb.pdf.

[4]. A. Ergün, A. E. Gürel ve İ. Ceylan, "Ticari tip soğutma sistemlerinde R22 akışkanının alternatifi olarak R438A ve R417A akışkanlarının performansının incelenmesi,", Gazi Üniversitesi Fen Bilimleri Dergisi Part C: Tasarım ve Teknoloji, cilt 6, no. 4, pp. 824-833, 2018.

[5]. A. La Rocca, V. La Rocca, A. Messineo ve D. Panno, "Use of HFC fluids as suitable replacements in lowtemperature refrigeration plants,", Journal of Engineering and Applied Sciences, cilt 9, no. 1, pp. 74-79, 2014. 
[6]. Z. Cingiz, F. Katırcıŏlu, Y. Çay ve A. Kolip, "Buhar S1kıştırmalı Soğutma Sisteminde R22 Alternatifi Soğutucu Akışkanların Termodinamik Analizi," Politeknik Dergisi, 2020.

DOI: $10.2339 /$ politeknik.548115

[7]. M. Çalışan ve İ. Türkoğlu, "Termal Kameralar ve Uygulamaları,", Elektrik-elektronik ve Bilgisayar Sempozyumu, FEEB 2011, Elazı ğ, 2011.

[8]. M. Weinmann, J. Leitloff, L. Hoegner, B. Jutzi, U. Stilla ve S. Hinz, "Thermal 3D mapping for object detection in dynamic scenes,", ISPRS Annals of the Photogrammetry, Remote Sensing and Spatial Information Sciences, cilt 2, no. 1, p. 53, 2014.

[9]. F. Katırcıoğlu, Y. Çay ve Z. Cingiz, "Infrared image enhancement model based on gravitational force and lateral,", Infrared Physics and Technology, cilt 100, pp. 1527, 2019.

[10]. Climalife IDS Refrigeration Limited, "HFC Refrigerants," URL: https://www.climalife.co.uk/refrigerants-hfc-refrigerants. [Erişildi: 12 Nisan 2020].

[11]. Jiang, H., Zeng, L., ve Bi, B., "A comprehensive method of contour extraction for industrial computed tomography images,", Optics and Lasers in Engineering, 51(3), 286-293, 2013.

[12]. Duan, L., Yao, M., Wang, J., Bai, T., ve Zhang, L.," Segmented infrared image analysis for rotating machinery fault diagnosis,", Infrared Physics \& Technology, 77, 267$276,2016$.

[13]. Barbieri, A. L., De Arruda, G. F., Rodrigues, F. A., Bruno, O. M., ve da Fontoura Costa, L., "An entropy-based approach to automatic image segmentation of satellite images,", Physica A: Statistical Mechanics and its Applications, 390(3), 512-518, 2011.

[14]. Simone, G., Pedersen, M., ve Hardeberg, J. Y., "Measuring perceptual contrast in digital images,", Journal of Visual Communication and Image Representation, 23(3), 491-506, 2012.

[15]. T. Haigh, "Cleve Moler: Mathematical software pioneer and creator of Matlab,", IEEE Annals of the History of Computing, 30(1), 87-91, 2008.

[16]. The MathWorks, Inc., "Creating graphical user interfaces,", The MathWorks, Nantick, MA, 2002.

[17]. F. Katırcıoğlu, "Real-time infrared image processing for control and monitoring of greenhouse system,", Journal of Applied Remote Sensing, cilt 14, no. 2, p. 026503, 2020. 